\title{
Labouring for Livelihoods: Gender, Productivity and Collectivity
}

\author{
Bina Agarwal ${ }^{1}$ \\ Published online: 30 March 2020 \\ (c) The Author(s) 2020
}

\begin{abstract}
Current debates in India on work, employment and labour markets have paid rather little attention to three important distinctions: between sustainable livelihoods and labour force participation; between autonomously managing non-family enterprises versus participation in decision-making within the confines of family enterprises; and between cooperation among workers for larger economic returns versus atomised individuals competing for work or livelihoods in unequal markets. This paper conceptually outlines the importance of focusing on work through the lens of livelihoods, autonomy and collectivity, especially for women. Empirically, it analyses whether group farming, wherein women farmers voluntarily pool land, labour, capital and skills to cultivate jointly, while sharing costs and benefits, can help them overcome their production constraints, create viable livelihoods, and gain autonomous identities as farmers? How well can women's group farms perform in comparison with malemanaged small family farms? Based on meticulously undertaken primary surveys of group farming in Kerala and Telangana, the paper compares all-women group farms with largely male-managed small family farms in the same state, in terms of productivity and profits. It also examines the impact on women's skill capabilities and status, which state is more effective and why, and the lessons these experiences hold for replication elsewhere. New and emerging experiments with farmers' collectives in eastern India and Gujarat, including all-male and mixed-gender groups, suggest that the group farming model can be adapted effectively to varying contexts. The paper thus demonstrates the importance and potential of transforming the institutions within which work is done, in order to enhance both worker well-being and productivity gains. In conclusion, it reflects on the concept of the Social and Solidarity Economy.
\end{abstract}

Keywords Viable livelihoods · Autonomy · Gender · Farmer collectives · Group farming $\cdot$ Cooperation $\cdot$ India

Bina Agarwal: Global Development Institute, University of Manchester, UK (bina.agarwal@manchester.ac.uk).

This paper is based on the V.V. Giri Memorial Lecture I delivered at the Indian Society for Labour Economics Conference in Patiala, December 2019. For the empirical results, it draws especially on my papers, Agarwal (2018, 2019a).

Extended author information available on the last page of the article 
It is a great honour to be asked to deliver the V.V. Giri Memorial Lecture. Dr. Giri, former President of India, was also the founder of the Indian Society of Labour Economics (ISLE) and continued to guide it till he passed away in 1980. He was a great believer in the power of the collective. He founded the All India Railwaymen's Federation in 1923 and served as President of the All-India Trade Union Congress. It is thus particularly appropriate that the centrepiece of my presentation will be on the importance of collectivities. This paper, based on the lecture, focuses first on three conceptual issues, then illustrates them through an empirical example from my current research and concludes with broad reflections.

\section{Conceptual Issues}

In current debates on work, employment and labour markets in India, three important aspects, which have been largely sidelined, need particular attention. First, it is important to make a conceptual distinction between labour force participation/ employment and sustainable livelihoods. Second, we need to distinguish between participating in decision-making within family enterprises and autonomously managing non-family enterprises. Third, it is necessary to distinguish between workers as atomised individuals competing in labour markets for the benefit of a few, and workers as people who can potentially cooperate in collectives for the benefit of the many. The three aspects are interconnected, as is illustrated here for the agricultural sector.

\section{Employment versus livelihoods}

Today, most debates on the working population tend to focus on jobs and labour force participation rates rather than on viable livelihoods. This is true even of feminist economics research on India where few issues have received more attention in recent years than women's falling labour force participation rate. ${ }^{1}$ This overwhelming attention to labour force participation makes invisible the raison d'être for which most people work, namely achieving decent livelihoods. For this purpose, rural informal sector workers-male and female-often have mixed portfolios, working not just on their own farms but also doing agricultural wage work seasonally, or taking up non-farm jobs. This is even more true of households which survive on multiple income sources, some members farming, others migrating to cities for jobs, yet others working on government projects, or being self-employed. A focus only on labour force participation cannot capture a household's vulnerability to poverty nor its livelihood potential and diversity.

\footnotetext{
${ }^{1}$ See, as a sample, Fletcher et al. (2018), Mehrotra and Parida (2017) and Dube et al. (2017), among others.
} 
Second, labour force participation alone does not capture labour productivity issues which are important and linked to efficiency, skill development, access to new technology, and so on.

Third, a preoccupation with labour force participation rates limits the nature of data gathered and the analysis undertaken. There is perhaps too much dependence on the National Sample Survey (NSS) and other labour force data. Each new round of the NSS, for example, is followed by criticism of the data's inability to fully capture women's work. In fact, I wrote about the undercounting of women workers in the census and NSS some 35 years ago (Agarwal 1985). Yet we are still talking about many of the same issues!

At the same time, India lacks the kind of Living Standards and Measurement Surveys conducted by the World Bank in many countries. The Indian Human Development Survey (IHDS), conducted by the National Council of Applied Economic Research (NCAER) and the University of Maryland, comes close, but has its own limitations. Is it lack of data which prevents more focus on livelihoods, or is it a neglect of a livelihood perspective which explains the limited data available?

\section{Autonomy}

The second complex issue is that of women's autonomy. Within rural family enterprises, women are typically embedded as unpaid workers with little autonomy. Efforts to capture their participation in household decision-making barely scrape the surface in terms of measuring this dimension. What matters is not simply women's ability to have a say in decisions relating to a family enterprise (be it a farm or a shop), but also their ability to work, to earn and to control their earnings independent of the family enterprise. It is outside-family options which tend to have the most impact on intra-household bargaining power (Agarwal 1997). This is not very different from the way labour markets operate, where an alternative job offer can significantly increase a person's bargaining power with a current employer.

\section{Collectivity}

The third issue is the continued focus on workers as individuals and not enough on the institutions within which they work, as Gerry Rodgers also pointed out in his Presidential address (Rodgers 2020, this volume). And a key institutional form is the collective, which (as noted earlier) Dr. V.V. Giri was also keenly interested in.

Of course collectives can take many forms, trade unions are only one. Associations, group enterprises and micro-credit groups are all collectives. The SelfEmployed Women's Association (SEWA) in India is an important example, as are Self-Help Groups (SHGs) and their federations. There is a widespread belief in civil society that collectives are essential for women's social empowerment-yet, with some exceptions such as SEWA, this belief rarely extends to economic empowerment. Hence, in our discussions on work in India today, we hear rather little about workers' collectives. This needs to change. 
In fact, the International Labour Organisation (ILO) website contains information of many collectives under the rubric of the Social and Solidarity Economy (SSE), which recognises the role of collectives in creating decent work. While the idea of an SSE is still evolving, there is agreement that it covers various forms of citizens' associations (social movements, SHGs, etc.) which cooperate for production and exchange in inclusive ways and interact with the State and markets through or on behalf of citizens.

So how do we bring these three ideas-livelihoods, autonomy and collectivitytogether, in relation to women's work and their economic empowerment? In fact, they come together beautifully and effectively in women farmers' collectives which I have been researching for several years.

\section{The Case for Group Farming}

1. Background

Despite the fall in women's labour force participation (including in agriculture) in recent years, even by the latest 2017-2018 labour force survey women constitute $30 \%$ of all farm workers, and agriculture still employs $73 \%$ of rural women workers. However, small farmers in general and women farmers in particular are seriously resource constrained, especially in terms of land access. Some $86 \%$ of Indian farmers cultivate two hectares or less (GoI 2019).

For women, the land constraint is vastly greater than for male farmers, given the enormous gender gap in land ownership. Although we lack accurate comprehensive national-level land ownership data by gender, my recent assessment based on a reliable agricultural data set for nine states shows that in 2014 only $14 \%$ of all landowners were women, owning only $11 \%$ of agricultural land (Agarwal et al. 2020). Although south India does somewhat better than other regions due to its less restrictive social norms, even in the south the gap is wide. Women also face gender bias in access to irrigation, credit, technology, information, state subsidies and markets (FAO 2011, World Bank 2009). As a result, as a recent paper based on IHDS data shows, women-managed family farms have $7 \%$ lower productivity than male-managed family farms (Mahajan 2019).

At the same time, within male-managed family farms, women typically lack both autonomy in decision-making and independent identities as farmers. Yet such is the grip of the idea of family farming that none of the many gendered studies on Africa and the few on $\mathrm{Asia}^{2}$ have asked the question: Would productivity and profits on women-managed farms rise if women worked as a group?

In other words, could a solution to the low productivity on women-managed farms lie in farming models which bring women together to farm in groups? Could, for example, group farming, involving resource pooling and joint cultivation help women farmers overcome their resource constraints and enhance their productivity

2 See Agarwal (2014a) for a review of these studies. 


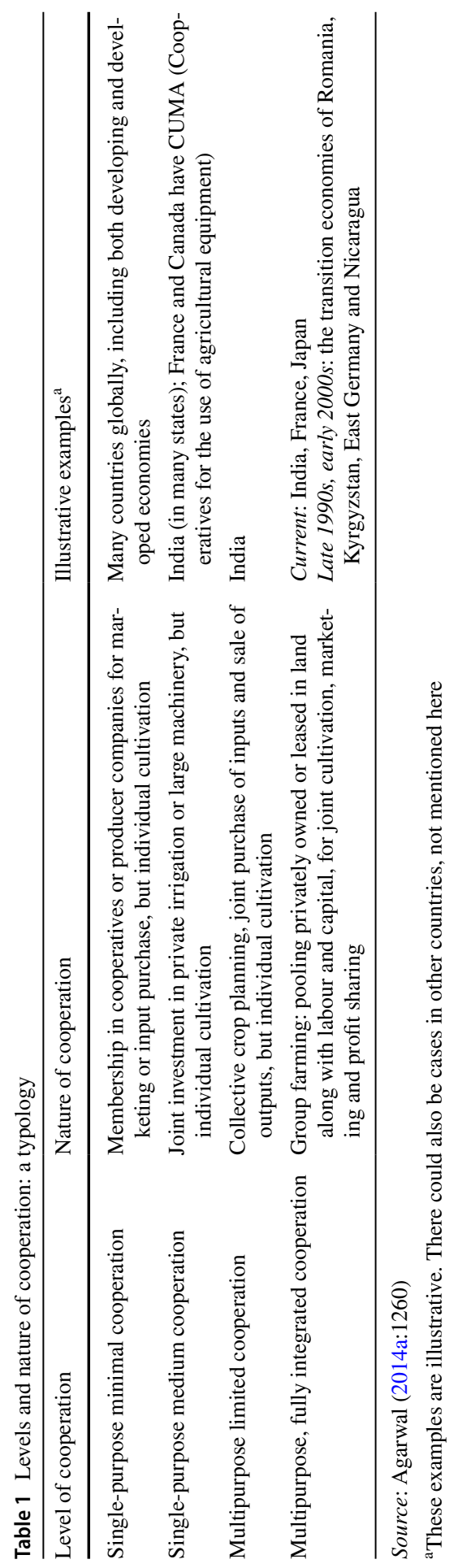


and profits? Can it also empower them socially and politically? I found a unique chance to address these questions empirically, based on experiments with group farming in two states of India-Kerala and Telangana. The answers (as detailed in Sect. 4) are striking.

\section{Levels of cooperation}

What are group farms? I use this term rather than the term 'cooperatives', since cooperatives can mean different things in different contexts. Cooperation in farming can range from single purpose to multipurpose to fully integrated (Table 1). Globally, single-purpose marketing cooperatives are most common, especially in the dairy industry. Amul in India is a case in point. In between, we find single- or multipurpose medium cooperation, such as for buying machines or crop planning. But group farming goes much beyond these. It involves resource pooling for collective production and fully integrated cooperation on a daily basis.

The idea of group farming is not new. Globally, the most famous (one might even say infamous) is socialist collectivization, which had largely negative effects on both production and farmers' welfare (see Agarwal 2010 for a review). But, in the 1960s, India also promoted farmer cooperatives (as did many post-colonial developing countries) as part of agrarian reform (Shivamaggi 1958; Goyal 1966). These groups too largely failed. Among important reasons for the failure were top-down implementation, large group size, and the attempt to involve both large and small farmers without recognising their conflicting interests.

Also, all earlier collective ventures (socialist and non-socialist) were highly gender unequal. Even in the USSR, women in collective farms were concentrated in manual jobs designated less skilled and carrying lower pay. For example, only $0.8 \%$ of tractor drivers and $1.4 \%$ of machine handlers were female, and $85 \%$ of women employees were labelled 'unskilled' (Swain 1985: 99). India's 1960s efforts too were gender unequal. They brought together family members into collectives, leaving women embedded in traditional divisions of labour, and not as farmers in their own right.

However, in the early 2000s, we see the emergence of a very different model in Kerala and Telangana. Both states encouraged rural women (and only women) to lease in land collectively, pool their labour and capital, and cultivate jointly. They are voluntarily constituted, egalitarian, and managed entirely by women. Notably, they are a collective of individuals, not a collective of family farms. And they recognise women as farmers in their individual capacity outside the domain of family farms. Hence, they give women autonomy in decision-making and independent identities as farmers. But how productive and profitable are they? 


\section{Potential gains}

Conceptually, we may expect resource pooling and joint cultivation to bring economic benefits to small farmers in general, male or female. For example, group farming could help enlarge farm size through pooling owned or leased land. This would improve economic viability and help reap economies of scale. Assessments for all India by Foster and Rosenzweig (2011) show that an increase in farm size from very small up to 8 ha, and especially up to 2 ha, significantly increases profits per ha.

Groups can also have other potential benefits. They can, for instance:

- help save on hired labour,

- enlarge the pool of funds and inputs,

- tap into a greater diversity of skills than found in one person or family,

- help farmers experiment with risk-prone higher value crops with larger payoffs,

- spread losses among a greater number,

- enable farmers to better deliver on contracts, and

- raise farmers' bargaining power in markets and with the government.

In addition, for women farmers, a group would help them better access land and markets, overcome social restrictions on their public interactions, and keep control over output.

To test whether some of these potential gains translate into gains in practice, I undertook primary surveys in Kerala and Telangana over 2012-2014, for a sample of group farms and individual family farms (95\% if which were male managed). This was the first systematic empirical analysis of group farming in India (or in developing countries more generally).

\section{Empirical Analysis: Women Farmers' Collectives}

\section{Genesis}

Kerala began its programme in the early 2000s. The initial idea came from village women who had experimented with leasing land in groups. But the larger programme was crafted by senior government officials and intellectuals under a participatory planning exercise (for details see Agarwal 2019b).

The programme is supported by the state government's Poverty Eradication Mission, or Kudumbashree Mission (K. Mission), as well as the Kudumbashree community network (K. Network). The latter is constituted of autonomously registered Community Development Societies at the panchayat level, with elected representatives from area development societies at the ward level and neighbourhood groups (NHGs) at the village level. Kerala modified the SHG model to constitute villagelevel NHGs as savings-cum-credit groups. Group farms are constituted by women who are members of NHGs or belong to households with an NHG member. 
The groups can access subsidised credit through the National Bank for Agriculture and Rural Development (NABARD). From the K. Mission they also get a startup grant, technical information, training from experts and crop-specific incentives. All this somewhat levels the playing field for women relative to men, but not fully. It is important to recognise that although most of the women who form group farms have worked on their family farms, few have managed a farm themselves, which requires making all the decisions and overseeing the whole range of operations. In 2018, there were over 64,000 such farms across Kerala, involving some 3 lakh women.

In Telangana, group farming was launched in 2001 by the UNDP (Delhi) and the Government of India, under a 5-year programme of support. It was implemented through the Andhra Pradesh Mahila Samatha Society (APMSS), a quasi-NGO which was already implementing the Mahila Samkhya programme (a programme for women's empowerment through education) in the state. APMSS encouraged the pre-existing sanghas or women's collectives (one per village), to take up group farming in 500 villages. Typically, all sangha members in the project villages joined.

Here too, each group received a small grant, implements, training and other support, but less than in Kerala. Also, government support ended once UNDP funding ended in 2005. Yet, encouragingly, $50 \%$ of the 500 groups continued to farm, overseen by APMSS, when I began my research.

\section{Data}

I collected data to compare women's group farms in each state with mostly malemanaged small family farms of 2 ha or less in the same state. I wanted to test whether group farms were more productive and profitable than family farms, as we would expect conceptually.

The Kerala sample consisted of 250 farms (69 all-women groups and 181 individual family farms) in two districts: Alappuzha which is dominated by paddy and Thrissur which is dominated by commercial crops, especially banana. Both districts grow vegetables. The individual farms were the family farms of the women members, but selected randomly from among them.

The Telangana sample consisted of 763 farms of which 70 were all-women group farms and 693 were individual farms owning 2 ha or less in three semi-arid districts: Mahbubnagar, Medak and Karimnagar. Here, the individual farms were of two types: the sangha women's family farms and non-group farms, selected randomly from farmers owning 2 ha or less in the study villages.

Weekly data were collected for every input and output for each crop and season, over an entire calendar year. Labour input data were collected by type of labour and machine used, operation-wise. Collecting such detailed data at such frequent intervals was a complicated and ambitious exercise. Most studies tend to use one-time or one-season memory recall to collect such data. The latter methods, however, cannot provide the needed accuracy, especially on labour used. 


\section{Characteristics}

Group farms can be constituted by leasing in land, or pooling the members' own land, or a mix of both. But since rather few women own land, they have few alternatives to the land-lease model, with its noted constraints. Hence, in both the Kerala and Telangana initiatives, women's groups lease in land, pool labour and capital, and share costs and benefits. If the leased land belongs to a group member, the rent is settled in advance, and the member is expected to contribute the same labour and costs as other members. Leases are mostly on a cash basis. The women can also work alongside their family farms, or take up occasional wage work. This is possible due to flexible task rotation on the group farms.

Kerala's sample of group farms had on average six members who were all literate and two-thirds had completed secondary school or more. The groups were heterogeneous across caste and religious lines and included both poor and less-poor homes. This heterogeneity goes against the common assumption in most collective action theory that homogeneity facilitates effective cooperation. Some heterogeneity was consciously promoted for three reasons: first to embed the groups in neighbourhoods which are themselves heterogeneous; second to ensure leadership. The K. Mission's logic was that local women's leadership comes not from the poorest but from those just above the poverty line. Third, heterogeneity provides a wider base of social capital for accessing land. In contrast, Telangana's groups had an average of 22 members. (Some even had 54 members.) Most were scheduled caste and only $38 \%$ were literate.

In both states, almost all women members came from small landowning families. In the Kerala sample, the average group farm was almost 1 ha in size relative to an average individual farm of 0.35 ha. In Telangana, the group farms were 2 ha on average, while individual farms were 1 ha. All the groups leased in land, while the individual farmers owned all or most of the land they cultivated.

Women's groups thus face at least four initial disadvantages relative to the largely male-run family farms:

- Their dependence on leased land involves high transaction costs in finding suitable land in a single plot, and creates insecurity of tenure since leases are oral.

- Oral leases also mean that women lack proof of being farmers and therefore cannot easily access government subsidies.

- The women face structural gender biases in access to land, inputs, extension services, machines and markets, and often fail to get inputs in time.

- Few have prior experience in managing farms.

Despite their challenges, how well did the women's collectives do vis-a-vis the largely male-managed individual family farms? In Kerala the groups did strikingly well, in Telangana less so. 


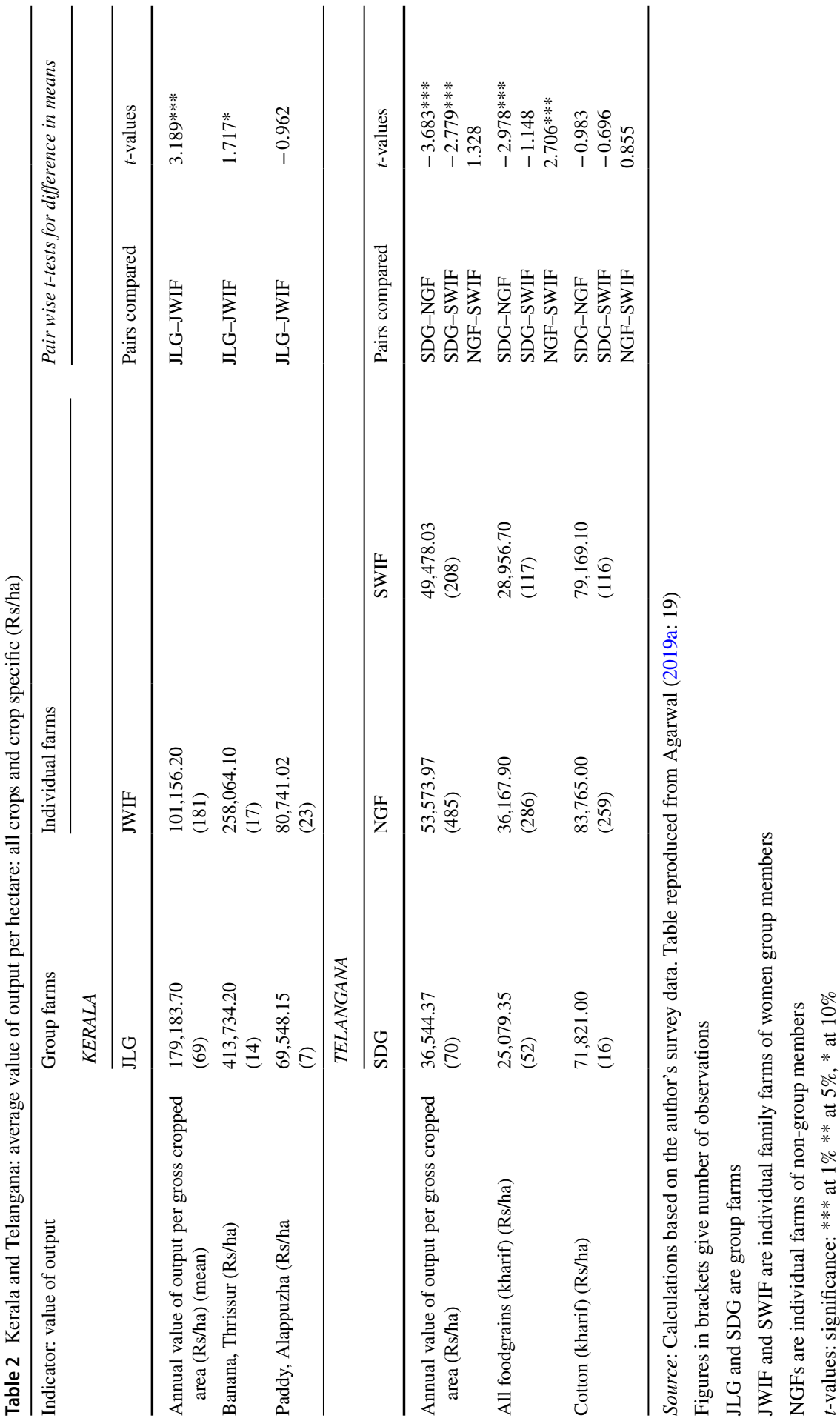




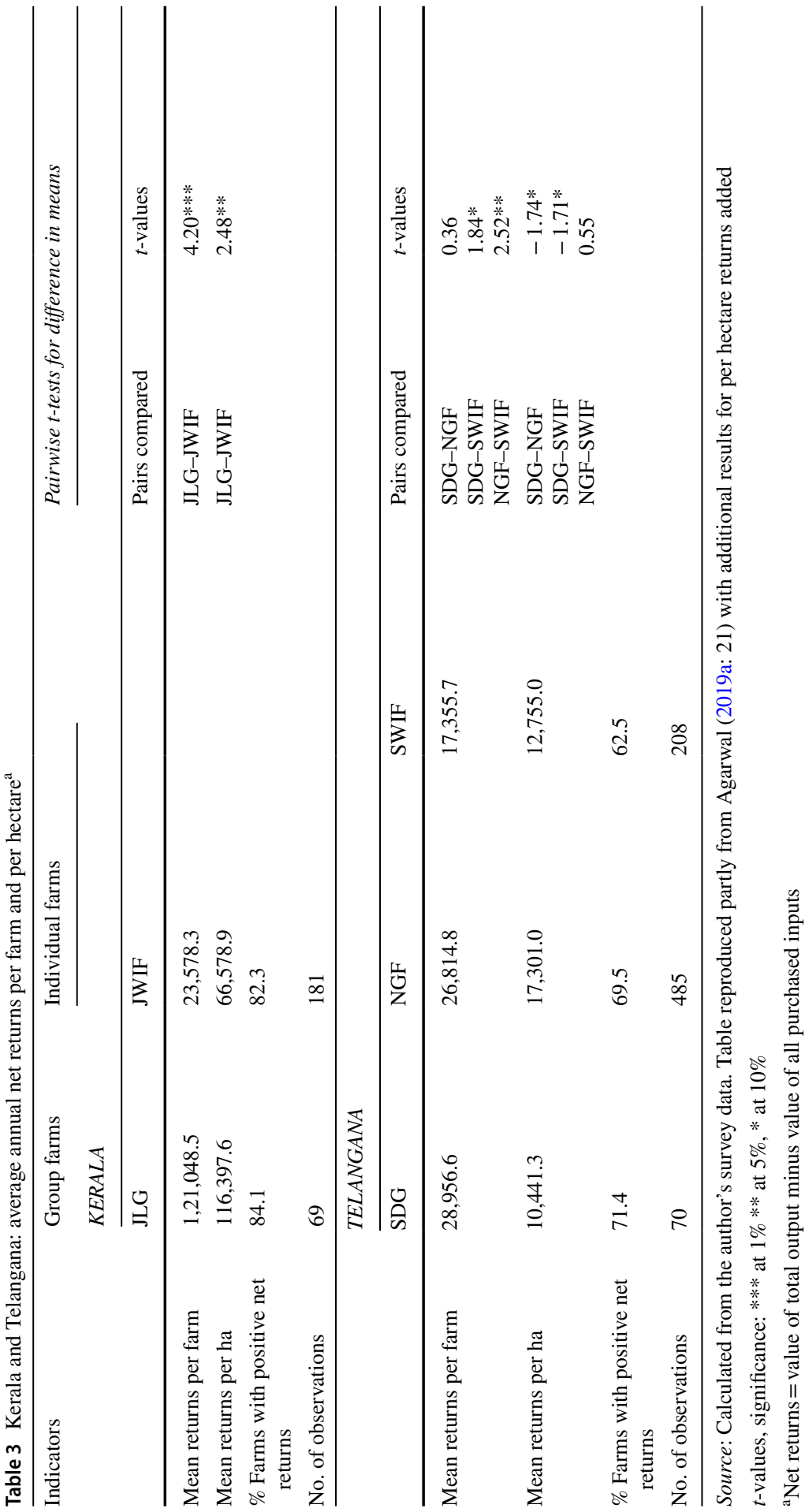




\section{Results}

\section{Productivity and profitability}

In Kerala, taking both districts together, group farms relative to individual family farms were found to have 1.8 times the average annual output per ha (Table 2). In banana, group farms had 1.6 times the average yields of individual farms. The banana story is noteworthy. The women's groups were able to work the market especially well. Some negotiated contracts with local temples to supply special banana varieties. As groups they could ensure delivery better than small individual farmers. Only in paddy did the women's groups perform less well than individual farms, largely due to a lack of good quality land on lease. Male owners preferred to cultivate good paddy land themselves. These results were supported by my regression analysis which controlled for input use, labour time, land size and other factors (see Agarwal 2018).

In Telangana, however, group farms performed worse than individual farms in their annual value of output per ha for all crops and for foodgrains alone. But they performed almost as well as individual farms in commercial cotton. APMSS, which promoted and supported these groups, strongly encouraged them to grow foodgrains and not cotton, arguing that cultivating foodgrains would increase their food security. In fact, this emphasis on growing foodgrains for food security is a common assumption in civil society. In the Telangana context, in a semi-arid zone with limited irrigation, this was perhaps not the best choice, since it left the women's groups vulnerable to low output.

Now consider the net returns (Table 3). These were calculated by deducting all paid out costs from the total value of output. In Kerala, the per farm mean net return per farm was found to be five times higher on average for the group farms than the small individual farms and three times that year's state average. The per hectare returns were 1.8 times higher on group farms. Indeed, even in Telangana, group farms made up for their low productivity in their annual net returns per farm (although less so on per hectare returns), since they spent less on hired labour.

\section{Comparing Kerala and Telangana}

Overall, why did Kerala do so well and Telangana get poor or mixed results. Five types of factors appear to underlie the divergent performances.

First, state support was key. Kerala's groups received continuing government support, including technical training and incentives. They also took advantage of subsidised credit from NABARD. In Telangana, state support was limited to 5 years and was at best partial.

Second, the organizational structure was important. Kerala's autonomous community development societies were able to negotiate effectively on behalf of the group farms with the state government's K. Mission and with the village panchayat. Telangana's sangha federations had limited negotiating power with the government. 
The third factor was group composition and size. Kerala's group members were heterogeneous, educated, and relatively young, and had wide social networks. Telangana's groups were largely composed of poor SC women with a limited social base, and many were illiterate. Kerala's smaller groups also enabled high per capita returns and easier coordination. In Telangana's groups, with 22 members on average, the per capita returns were small and coordination of labour time was more complicated.

The fourth factor relates to production conditions. Kerala gained by choosing more commercial crops. It also had favourable local ecology with high rainfall and irrigation. Telangana lost by an overemphasis on foodgrains in a semi-arid climate with poorly developed irrigation.

The fifth was the conceptualisation of the programme. Kerala focused on livelihood enhancement and interlinked social empowerment. Telangana introduced group farming to women who were part of a pre-existing programme for social empowerment. For empowering women socially, a large group size can be more effective, but for economic production large groups can become a constraint.

Nevertheless, in both states, group farming, catalysed by external interventions, has provided women farmers an important alternative to being unpaid workers on family farms.

\section{Capability enhancement and autonomy}

Beyond production, qualitative evidence indicates that group farming has enhanced women's capabilities and transformed their lives. The women have developed stronger identities as farmers who are recognised by the community as having technical skills and capabilities. They have become familiar with a wide range of public institutions and services. They have also learnt to negotiate in multiple markets for land and inputs, as well as in market yards for storing their produce. Most importantly, women take production decisions and manage the farms independently. This is a notable advantage in terms of giving them autonomy.

In addition, women report being more respected within families and communities (see Agarwal 2019a for details). And in most cases they say they control the income from the group farms. Also, in both states, many group farm members have been standing for and winning in panchayat elections.

\section{Beyond Kerala and all-women groups}

Is group farming only relevant for women, and only for Kerala? It does not appear to be so. In 2015, the International Water management Institute in Nepal successfully launched 20 group farms in Bihar, North Bengal and Terai Nepal, overseen by local NGOs. These group farms are diverse: they include all-women groups, allmale groups and mixed-gender groups. Some pool owned land; others lease land wholly or partly (Sugden et al. 2020).

In Bihar and Nepal, these group farmers have been able to challenge local feudal relations by standing up to landowners from whom they lease in land. For example, 
one group was able to negotiate lower rents; another refused to provide landowners with unpaid labour by their family members; and yet another refused to allow the landlord's family to pick vegetables from their fields without payment.

Cultivating larger and contiguous plots by consolidating their land has made land preparation and irrigation easier. They are able to use tractors more effectively and also irrigate the fields more efficiently, saving the time otherwise needed to move a heavy pumpset between distant plots. In fact, for many farmers irrigation with electric pumpsets was not even feasible earlier, where their scattered plots had no nearby power supply. The farmers have also gained from economies of scale and saved on hired labour and input costs. The joint effect of irrigation and group farming has helped them increase cropping intensity, crop diversity and yields. Also women have learnt to use the irrigation technology. Notably, too, some youth groups have taken up group farming instead of migrating for uncertain jobs in the cities.

In another region, Gujarat, following a workshop I was invited to conduct in 2018 by several NGOs working on rural livelihoods or women's land rights, one NGO, Cohesion, launched 16 women's group farms. Their impact on women's productivity and lives remains to be assessed.

\section{Reflections}

This paper emphasises the need to reconceptualise work and employment in all their dimensions, especially for women, taking into account the contributions of work and employment not only to economic well-being but also to other personal and social goals, including status and autonomy. No single indicator, least of all the female labour force participation rate, can capture the full measure of this complexity. Moreover, work and employment cannot be separated from the wider institutional and structural contexts within which they take place.

The empirical examples of group farming demonstrate that institutional innovations could prove key to reviving agricultural livelihoods. Collectives can reduce the effect of state and market failures for the disadvantaged. They can help bridge, to a fair extent, both the gender resource gap and the gender productivity gap in agriculture, and enable women to operate with autonomy as farm managers. They give us insights into women's capabilities, and their ability to cooperate and create livelihoods that simply focusing on their labour force participation cannot. The examples studied also hold lessons for replication in other regions, in terms of both what should be done and what should be avoided. However, forming a collective cannot, in itself, help to bridge the gender gap in land ownership which continues to be a barrier. This research thus highlights the complexities involved in efforts to transform agriculture, even while offering positive trajectories for innovative institutional change.

A related question is: Can we see these women's group farms as part of the Social and Solidarity Economy (SSE)? In so far as operating successfully in groups is concerned, we clearly can. At the same time, moving from a group approach in one sector to a solidarity approach for an entire economy is not likely to be easy, if at all feasible. At present, we barely have some localised networks of interconnected 
institutions. Kerala, for instance, has Padasekara samities which do watershed development for paddy farmers. In France, many group farms are linked to CUMA, the farmers' machine cooperatives. But these are still sectoral links. To build an entire economy and society on cooperation rather than on competition, would require a vastly different vision and transformative agenda. How this should be approached cannot be answered in this paper, but it opens up an entire area for further conceptual and empirical research.

Also, the SSE discussion has not addressed a key question: What motivates people to cooperate? Is it just enlightened self-interest, or is there also some sense of solidarity beyond self-interest? Here, it is useful to distinguish between what I term 'strategic solidarity' from what I term 'empathetic solidarity'. The examples of group farming given above display both. The farmers began with strategic solidarity-they came together expecting economic gain through group farming. But over time, empathetic solidarity has also emerged-women help each other in times of need, visit each other in hospital when someone is ill, and in Telangana, the groups allow elderly women to participate even if they cannot contribute much labour, on the grounds that they provide knowledge and experience.

Indeed, while collectives may initially be built on enlightened self-interest for strategic benefits, this may need to change, as we think of the many problems facing our societies and economies, including climate change. Here, moving from selfinterest to other-regarding interest and from individual to collective responsibility appears deeply necessary.

Other-regarding interest is not only a female trait. It can be seen as a universal trait, one which even Adam Smith (1966:1) — that doyen of free competition-recognised in his Theory of Moral Sentiments when he said:

How selfish soever man may be supposed, there are evidently some principles in his nature which interest him in the fortune of others..., though he derives nothing from it except the pleasure of seeing it.

There is, in fact, a growing body of work in behavioural economics which demonstrates that altruism, inequality aversion, and a social preference for fairness counter narrow self-interest and affect labour market outcomes in unexpected ways (see papers in Agarwal and Vercelli 2005). Indeed, as many group farmers (both women and men) argue, cooperation is often worth it simply because you enjoy working together.

Perhaps, these joys and other-regarding social preferences will provide the corner stones for building an economy and society that will rest more on cooperation than on competition!

Open Access This article is licensed under a Creative Commons Attribution 4.0 International License, which permits use, sharing, adaptation, distribution and reproduction in any medium or format, as long as you give appropriate credit to the original author(s) and the source, provide a link to the Creative Commons licence, and indicate if changes were made. The images or other third party material in this article are included in the article's Creative Commons licence, unless indicated otherwise in a credit line to the material. If material is not included in the article's Creative Commons licence and your intended use is not permitted by statutory regulation or exceeds the permitted use, you will need to obtain permission directly from the copyright holder. To view a copy of this licence, visit http://creativecommons.org/licen ses/by/4.0/. 


\section{References}

Agarwal, B. 1985. Work participation of rural women in the third world: Some data and conceptual biases. Economic and Political Weekly 51-52: 155-164.

Agarwal, B. 1997. Bargaining and gender relations: Within and beyond the household. Feminist Economics 3 (1): 1-51.

Agarwal, B. 2010. Rethinking agricultural production collectivities. Economic and Political Weekly 55 (9): 64-78.

Agarwal, B. 2014a. Food security, productivity and gender inequality. In Handbook of food politics and society, ed. R. Herring. New York: Oxford University Press.

Agarwal, B. 2014b. Food sovereignty, food security and democratic choice: Critical contradictions, difficult conciliations. Journal of Peasant Studies 41 (6): 1247-1268.

Agarwal, B. 2018. Can group farms outperform individual family farms? Empirical insights from India. World Development 108: 57-73.

Agarwal, B. 2019a. Does group farming empower women? Lessons from India's experiments. Journal of Peasant Studies. https://doi.org/10.1080/03066150.2019.1628020.

Agarwal, B. 2019b. The interplay of ideas, institutional innovations and organisational structures: Insights from group farming in India, ESID Working Paper No. 116, Global Development Institute, University of Manchester.

Agarwal, B., Anthwal, P., and Mahesh, M. 2020. Which women own land in India? Between diverse data sets, measures and laws, draft. University of Manchester UK.

Agarwal, B., and S. Vercelli. 2005. Psychology, rationality and economic behaviour: Questioning standard assumptions. London: Palgrave.

Dube, A., W. Olsen, and K. Sen. 2017. The decline in the labour force participation of rural women in India: Taking a long-run view. Indian Journal of Labour Economics. 60: 589-612.

FAO. 2011. The state of food and agriculture report. Women in Agriculture. Rome: UN FAO.

Fletcher, E., R. Pande, and C. Moore. 2018. Women and work in India: Descriptive evidence and a review of potential policies. Faculty Research Working Paper Series, Harvard Kennedy School.

Foster, A. D., and M. Rosenzweig. 2011. Are Indian farms too small? Providence: Brown University, mimeo.

GoI. 2019. Agricultural census of India, 2015-16, All India Report on Number and Area of Operational Holdings, Government of India.

Goyal, S.K. 1966. Cooperative farming in India. Bombay: Asia Publishing House.

Mahajan, K. 2019. Back to the plough: Women managers and farm productivity in India. World Development 124: 104633.

Mehrotra, S., and J. Parida. 2017. Why is the labour force participation of women declining in India. World Development 98: 360-380.

Rodgers, G. 2020. Labour and employment in India: A 50-year perspective. Indian Journal of Labour Economics, 63(1). https://doi.org/10.1007/s41027-020-00204-x.

Shivamaggi, H.B. 1958. Cooperative farming in India. Indian Journal of Agricultural Economics 5 (2): $139-153$.

Smith, A. 1759 [1966]. The theory of moral sentiments, vol. 1. Reproductions of economic classics. New York: Augustus M, Kelly.

Sugden, F., B. Agarwal, S. Leder, P. Saikia, M. Raut, A. Kumar, and D. Ray. 2020. Experiments in farmer collectives in eastern India and Nepal: Process, benefits and challenges, mimeo.

Swain, N. 1985. Collective farms which work? Cambridge: Cambridge University Press.

World Bank. 2009. Gender in agriculture sourcebook. Washington, DC: World Bank.

Publisher's Note Springer Nature remains neutral with regard to jurisdictional claims in published maps and institutional affiliations. 


\section{Affiliations}

\section{Bina Agarwal ${ }^{1}$}

$\triangle$ Bina Agarwal

bina.agarwal@manchester.ac.uk

1 Development Economics and Environment, Global Development Institute, University of Manchester, Manchester, UK 